\title{
Functional Dyspepsia
}

\author{
Abdullah M Nasrat ${ }^{*}$ \\ Department of Surgery, Balghsoon Clinic, Jeddah, Saudi Arabia \\ *Corresponding author: Abdullah M Nasrat, Balghsoon Clinic, PO Box 5261 Jeddah 21573, Saudi Arabia, Tel: + 966 (012) 6673645 ; Fax: + 966 (012) 667 3645; E- \\ mail: abdullahalnasrat@yahoo.com
}

Rec date: June 25, 2015 Acc date: June 27, 2015 Pub date: June 30, 2015

Copyright: () 2015 Nasrat AM. This is an open-access article distributed under the terms of the Creative Commons Attribution License, which permits unrestricted use, distribution, and reproduction in any medium, provided the original author and source are credited.

\section{Letter to Editor}

Functional dyspepsia is a clinical syndrome defined by chronic or recurrent pain or discomfort in the upper abdomen of a variable origin. A general agreement exists on the irrelevant role played by Helicobacter pylori in the pathophysiology of most cases of functional dyspepsia worldwide $[1,2]$.

Diagnosis of $H$. pylori is based on the clinical symptoms and detection of $H$. pylori serum antibodies. The following clinical symptoms are considered; upper gastrointestinal pain, burping, gastric distension, halitosis, and hyperacidity. Specific sensitive diagnostic tests are available but $H$. pylori serum antibodies, though non-specific, is suggested because of being cost effective as the matter of $H$. pylori dyspepsia is a typical subject of cost-effectiveness [3].

It is necessary to effectively deal with $\mathrm{H}$. pylori dyspepsia due to its associated risk with gastric carcinoma, lymphoma and many reasons of chronic illness such as acid peptic disease, diabetes, hypertension, thyroiditis, carditis, dermatitis and nephritis through immune or different reasons [2].

The efficacy of antibiotic treatment for non-ulcer dyspepsia is controversial, different trails have given conflicting results. Overall, antibiotic eradication treatment for non-ulcer dyspepsia symptoms had no significant effect on quality of life compared with placebo and was found more costly if compared to antacid treatment [4,5] Bioorganic acids; lactic and acetic, have been proved effective in symptomatic and clinical cure of dyspepsia due to interference with $H$. pylori energy metabolism or its respiratory chain metabolism as the main source of energy for $H$. pylori are via pyruvate and the activity of the pyruvate dehydrogenase complex is controlled by the rules feedback regulation and product inhibition; lactate and acetate are demonstrated among the end products of pyruvate metabolism [6-8].

Eradication of clinical symptoms of $\mathrm{H}$. pylori-related dyspepsia is considered a clinical cure; patients who are rendered asymptomatic after treatment do not need further investigation or treatment, they can just return for re-assessment if they develop further symptoms. Evaluation of eradication after $\mathrm{H}$. pylori treatment markedly increases cost with no clear improvement in results [9].

H. pylori is not just a bad bug in all instances; the juxta-mucosal ammonia produced by $H$. pylori protects the gastric wall from its acid if it goes in excess. The residual ammonia inside the lumen of the stomach resulting from the buffering between the ammonia and the gastric acid is not toxic, it is even beneficial; functioning as smooth muscle tonic maintaining the integrity of the gastro-esophageal sphincter and hence preventing reflux [7].
Data from observational studies have proposed a protective role of $H$. pylori against the development of gastro-oesophageal reflux disease, and suggested that $H$. pylori eradication treatment may increase the incidence of reflux symptoms. It was observed that the prevalence of $H$. pylori has been decreasing in developed countries, while the prevalence of gastro-esophageal reflux disease and esophageal adenocarcinoma has been increasing since 1930s [9].

It was amazing to the team working with the author of this letter to get the news of a nine years old Saudi girl living with her family in Switzerland to have a diagnosis of reflux disease. The symptoms of this kid just all disappeared after stopping un-necessary antibiotics for every throat infection, restriction of outside-home meals and fast food in addition to intake of natural probiotics. Normal behavior $H$. pylori is supposed to be protective; it should not be kicked out from the stomach but saved.

\section{References}

1. Stanghellini V, De Ponti F, De Giorgio R, Barbara G, Tosetti C, et al. (2003) New developments in the treatment of functional dyspepsia. Drugs 63: 869-892.

2. Farinha P, Gascoyne RD (2005) Helicobacter pylori and MALT lymphoma. Gastroenterology 128: 1579-1605.

3. García-Altés A, Jovell AJ, Serra-Prat M, Aymerich M (2000) Management of Helicobacter pylori in duodenal ulcer: a cost-effectiveness analysis. Aliment Pharmacol Ther 14: 1631-1638.

4. McColl K, Murray L, El-Omar E, Dickson A, El-Nujumi A, et al. (1998) Symptomatic benefit from eradicating Helicobacter pylori infection in patients with nonulcer dyspepsia. N Engl J Med 339: 1869-1874.

5. Moayyedi P, Soo S, Deeks J, Forman D, Mason J, et al. (2000) Systematic review and economic evaluation of Helicobacter pylori eradication treatment for non-ulcer dyspepsia. Dyspepsia Review Group. BMJ 321: 659-664.

6. Midolo PD, Lambert JR, Hull R, Luo F, Grayson ML (1995) In vitro inhibition of Helicobacter pylori NCTC 11637 by organic acids and lactic acid bacteria. J Appl Bacteriol 79: 475-479.

7. Nasrat AM (2009) The world misconception and misbehavior towards Helicobacter pylori is leading to major spread of illness. The 7th AntiAging Medicine World Congress, Monte-Carlo, Monaco.

8. Phull PS Halliday D, Price AB, Jacyna MR (1996) Absence of dyspeptic symptoms as a test of Helicobacter pylori eradication. BMJ 312: 349-350.

9. Labenz J, Blum AL, Bayerdörffer E, Meining A, Stolte M, et al. (1997) Curing Helicobacter pylori infection in patients with duodenal ulcer may provoke reflux esophagitis. Gastroenterology 112: 1442-1447. 